\title{
DISTRIBUTION OF LARVAL AND POSTLARVAL ANTARCIIC FISHES AROUND ELEPHANT ISLAND AND BRANSFIELD STRAIT - ANTARCTICA.
}

\author{
Chossi Sinque * \\ Sigrid Koblitz * \\ Laura Marilia Costa *
}

\begin{abstract}
Distribution and abundance of larval and postlarval Antarctic fishes sampled by plankton nets, from the Oceanographic R/V "BARÃO DE TEFFE", around Elephant Island and Bransfield Strait, during the southern summer 1983/84 (PROANTAR II) and 1984/85 (PROANTAR III), were analysed. All the ichthyoplankton was composed of Nototheniidae (Pleuragramma antarcticum, Notothenia kempi, Notothenia larseni, Notothenia gibberifrons); Paralepididae (Notolepis coatsi); Myctophidae (Electrona antarctica) and Channichthidae (Champsocephalus gunnari). Of these P. antarcticum was the most abundant species followed by $\mathbf{E}$. antarctica. The greatest diversity of species (5) was found around Elephant Island.
\end{abstract}

Key words: Ichthyoplankton, Elephant Island, Bransfield, distribution.

\section{RESUMO}

\section{DISTRIBUiÇÃo de LARVAS E PÓS-LARVAS de PEIXES ANTÁRTICOS AO REDOR DA ILHA ELEFANTE E ESTREITO DE BRANSFIELD - ANTARTICA.}

Distribuição e abundância de larvas e pós-larvas de peixes antárticos coletadas com redes de plâncton, a bordo do NAPOc "Barão de Teffé", ao redor da llha Elefante e Estreito de Brans-

- Centro de Biologia Marinha - UFPR.

93.200 Pontal do Sul - Paraná 
field, durante o verão autral 1983/84 (PROANTAR II) e 1984/85 (PROANTAR III), foram analisados. O ictioplâncton era constituido de Nototheniidae (Pleuragramma antarcticum, Notothenia kempi, Notothenia larseni, Notothenia gibberifrons); Paralepididae (Notolepis coatsi); Myctophidae (Electrona antarctica) e Channichthyidae (Champsccephalus gunnari). A espécie mais abundante foi $\mathbf{P}$. antarcticum, seguida de $\mathbf{E}$. antarctica. $\mathrm{O}$ maior número de espécies (5) foi encontrado ao redor da Ilha Elefante.

Palavras chave: Ictioplâncton, Ilha Elefante, Bransfield, distribuição.

\section{INTRODUCTION}

Early life history stages of Antarctic fish fauna are still poorly understood but after the meeting of the Multinational BIOMASS Research Program in Paris, 1-4 September, 1981 the investigation in this field increased to achieve the main objective suggested by the working group. Recently, many scientists contributed in ichthyoplankton surveys to complement the knowledge on the ecology of adult fishes (Wörner and James, 1981; Hempel and Heywood, 1982; Mujica and Torres, 1982; North and White, 1982; Slosarczyk and Rembiszewski, 1982; Burchett et al., 1983; Efremenko, 1983; Keller, 1983; Rasoanarivo and Aboussouan, 1983; Kellermann and Kock, 1984; Hubold, 1985; Kellermann and Slosarczyk, 1985 and Sinque et al., 1986). Emphasis was also given to hydrographic analysis in the southern ocean of the Atlantic sector in areas of biological interest (Stein, 1979; Anon., 1982b; Ikeda et al., 1982; Anon., 1983; Stein and Suszczewiski, 1983), to better understand the relationships between the environment and the biology of Antarctic animals.

This paper reports about the species composition, distribution and abundance of larval and postlarval Antarctic fishes found around Elephant Island and Bransfield Strait.

All species caught in these areas were registered in Antarctic waters and the present results extend the limit of distribution to Elephant and adjacent islands.

\section{MATERIAL AND METHODS}

The plankton sampling stations around Elephant Island and Bransfield Strait realized during the southern summer 1983/84 
(PROANTAR II) and 1984/85 (PROANTAR III) are illustrated in Figs. 1-2.

The collections were made on board of the Oceanographic R/V "BARÃO DE TEFFÉ" using a modified cylindricconical net $(500 \mu \mathrm{m}$ mesh) for horizontal $(\mathrm{H})$ and oblique $(\mathrm{O})$ hauls and a closing net (C-325 $\mu \mathrm{m}$ mesh) for stratified sampling, both equipped with a calibrated flowmeter.

Hydrographic data were obtained at each station with Nansen bottles equipped with reversing thermometer at 50 meters intervals from the surface to the plankton sampled depths. Plankton was fixed and preserved in $4 \%$ buffered sea water formaldehyde. In the laboratory all the fish larvae and postlarvae were sorted, identified and counted. The species were identified according to Regan (1916), North and White (1982) and Efremenko (1983). The relative abundance is given in density (number of ind./1,000 $\mathrm{m}^{3}$ ). The standard length ( $\mathrm{SL}$ ) was measured to the milimeter below by means of an ocular micrometer mountend in Wild-M8 stereozoom dissecting microscope.

\section{RESULTS AND DISCUSSION}

The larvae and postlarvae Antarctic fishes were caught in $12(37,5 \%)$ of the 32 plankton sampled stations. All the material was collected in an epipelagic zone where the depths from the bottom ranged from 110 to 1240 meters (shallow waters over the shelf and continental slope).

The positively sampled stations data and percentage of larvae and postlarvae in the total catch are listed in TABLE I.

The density of the ichthyoplankton (Figs. 3-4) was higher at station 18 followed by station $\mathrm{H}$, both off Elephant Island.

Species composition, size, number and occurrence of larvae and postlarvae summarized in TABLE II show a greater diversity of species around Elephant Island than in Bransfield Strait. There are: Pleuragramma antarcticum Boulenger, 1902; Notothenia kempi Normann, 1937; Notothenia larseni Lönnberg, 1905 (Nototheniidae); Notolepis coatsi Dollo, 1908 (Paralepididae); Electrona antarctica Günther, 1878 (Myctophidae); and Champsocephalus gunnari Lönnberg, 1905 (Channichthyidae). In 
TABLE I. Positively sampled stations data of larvae and postlarvae Antarctic fishes around the Elephant Island and Bransfield Strait during the southern summer $1983 / 84$ and $1984 / 85$.

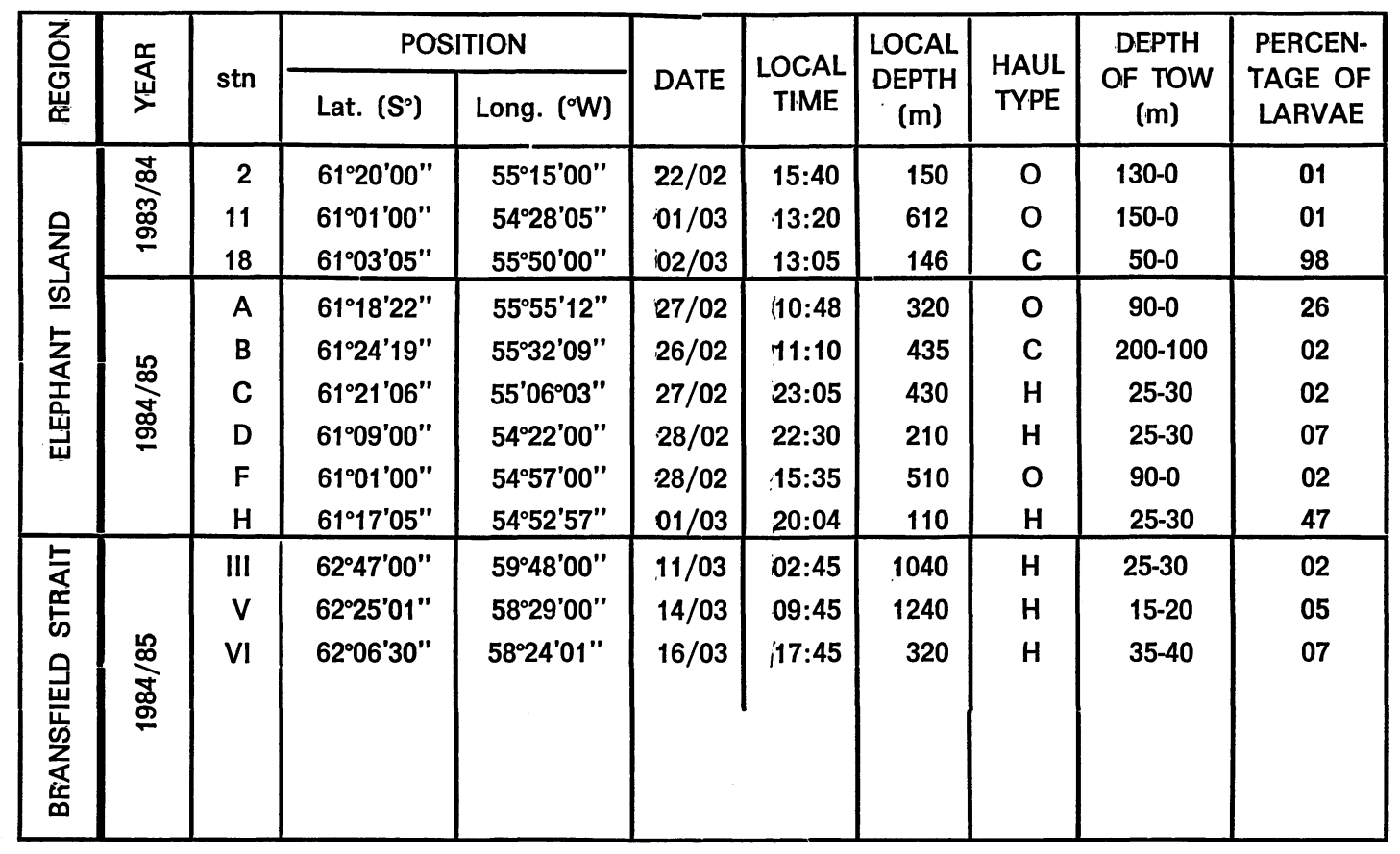


TABLE II. Species, size, number and occurrence of larvae and postlarvae of Antarctic fishes.

Southern summer 1983/84.

\begin{tabular}{|l|l|c|c|c|}
\hline \multicolumn{1}{|c|}{ TAXON } & COMMON NAME & NUMBER & $\begin{array}{c}\text { SIZE RANGE } \\
(\mathrm{mm})\end{array}$ & OCCURRENCE STN \\
\cline { 5 - 5 } & & & & ELEPHANT I \\
\hline NOTOTHENIIDAE & & 75 & $13.2-17.3$ & 2,18 \\
Pleuragramma antarcticum & Antarctic herring & 75 & $10.1-10.3$ & 18 \\
Notothenia kempi & Antarctic cod & 2 & $09.3-10.7$ & 18 \\
Notothenia larseni & Antarctic cod & 3 & & 11 \\
PARALEPIDIDAE: & & 1 & 34.1 & \\
Notolepis coatsi & lonah fish & 18 & \\
\hline
\end{tabular}

Southern summer 1984/85

\begin{tabular}{|c|c|c|c|c|c|}
\hline \multirow{2}{*}{ TAXON } & \multirow{2}{*}{ COMMON NAME } & \multirow{2}{*}{ NUMBER } & \multirow{2}{*}{$\begin{array}{l}\text { SIZE RANGE } \\
(\mathrm{mm})\end{array}$} & \multicolumn{2}{|c|}{ OCCURRENCE STATIONS } \\
\hline & & & & ELEPHANT I & BRANSFIELD S. \\
\hline $\begin{array}{l}\text { NOTOTHENIIDAE } \\
\text { Pleuragramma antarcticum } \\
\text { Notothenia gibberifrons } \\
\text { Notothenia kempi }\end{array}$ & $\begin{array}{l}\text { Antarctic herring } \\
\text { Antarctic cod } \\
\text { Antarctic cod }\end{array}$ & $\begin{array}{r}25 \\
3 \\
3\end{array}$ & $\begin{array}{l}11.3 .-23.0 \\
20.0-37.0 \\
09.0-16.2\end{array}$ & $\begin{array}{l}\text { A, H } \\
\text { A }\end{array}$ & $\begin{array}{l}\text { III, VI } \\
\text { VI }\end{array}$ \\
\hline $\begin{array}{l}\text { PARALEPIDIDAE: } \\
\text { Notolepis coatsi }\end{array}$ & lonah fish & 1 & 23.5 & B & \\
\hline $\begin{array}{l}\text { MYCTOPHIDAE: } \\
\text { Electrona antarctica }\end{array}$ & Lantern Fish & 20 & $04.4-7.9$ & $C, D, H$ & \\
\hline $\begin{array}{l}\text { CHANNICHTHYIDAE: } \\
\text { Champsocephalus gunnari }\end{array}$ & Ice Fish & 5 & $10.0-18.5$ & $A, F$ & V \\
\hline
\end{tabular}


the Bransfield Strait only 3 species were found: Notothenia gibberifrons Lönnberg, 1905; Notothenia kempi Normann, 1937 (Nototheniidae) and Champsocephalus gunnari Lönnberg, 1905 (Channichthyidae).

The reduced number of stations and limited areas of sampling probably contributed to the scarce number of species. Sinque et al. (1986), studying the samples caught in more extensive areas of Bransfield Strait during the southern summer 1982/83, obtained a more diversified number of species. The occurrence of many larval and postlarval fishes off the Antarctic Peninsula and surrounding areas related with the hydrographic conditions and water masses, originated by the complex interaction of adjacent waters of the Bellingshausen Sea, the Weddell Sea, the Southern Drake Passage and the Scotia Sea, were reported by Yefremenko (1980), Wörner and James (1981), Slosarczyk and Rambiszewski (1982), Efremenko (1983), Keller (1983), Kellermann and Slosarczyk (1985) and Sinque (1986).

The total abundance of larvae and postlarvae (Fig. 5) show that Pleuragramma antarcticum is dominant $(280,51$ ind./ 1,000 $\mathrm{m}^{3}$ ) followed by Electrona antarctica (129.23 ind./1,000 $\mathrm{m}^{3}$ ). Keller (1983) and Hubold (1985) also found high numbers of P. antarcticum (85-98\% among the fishes caught in the Weddell Sea).

The species density of larvae and postlarvae at different stations (Fig. 6) show a high concentration of. P. antarcticum at/ station 18 off the western coast and for E. antarctica at station $H$ in southern coast, both in Elephant Island. The size frequency distribution, in percentage, of these species is indicated in Fig. 7. The dominant size classes of P. antarcticum were $15 \mathrm{~mm} \mathrm{SL}$ and $19 \mathrm{~mm} \mathrm{SL}$, respectively, in 1983/84 and 1984/85. For E. antarctica the $5 \mathrm{~mm} \mathrm{SL}$ was the dominant class in 1984/85.

\section{ACKNOWLEDGEMENTS}

We wish, to express our thanks, first to the staff members of CIRM (Comissão Interministerial para os Recursos do Mar) for financial support and to the crew of the Oceanographic R/V "Barão de Teffé" of the Brazilian Navy for logistic support. 
We are particularly thankful to Commander Fernando Sérgio Nogueira de Araujo, Coordinator of PROANTAR (Programa Antártico Brasileiro) for his assistance and efforts in behalf of the project and Dr. Mónica Montú who contributed with plankton samples collected during the southern summer 1983/84.

Finally, our thanks to Dr. A. Kellermann from the Institute of Polar Ecology and Dr. Tagea K. S. Björnberg from "Universidade de São Paulo" for helpful suggestions and critical review on the manuscript.

\section{REFERENCES}

ANONYMOUS, 1982b. First post FIBEX hydrographic data interpretation workshop, Hamburg 20-26 September 1982. BIOMASS Report Ser., 30: 1-11. ANONYMOUS, 1983. Second post FIBEX hydrographic data interpretation workshop, Hamburg 16-20 May, 1983. BIOMASS Report Ser., 31: 1-26.

BURCHETT, M.; SAYERS, P.J.; NORTH, A.W. \& WHITE, M.G., 1983. Some biological aspects of the nearshore fish populations at South Georgia. Brit. Antarct. Surv. Bull., (50): 63-74.

EFFEMENKO, F.N.; 1983. Atlas of fish larvae of Southern Ocean. Cybium, 7(2): $1-74$.

HEMPEL, G. \& HEYWOOD, R.B., 1982. Joint biological expedition on BRS "John Biscoe", February 1982. Reports on Polar Res. (5): 1-39.

HUBOLD, G., 1985. Spatial distribution of Pleuragramma antarcticum (Pisces - Nototheniidae) near the Filchner and Larsen Ice Shelves (Weddell Sea/Antarctica). Polar Biol. Spring-Verlag (4): 1-6 (provisional page).

IKEDA, Y.; MIRANDA, L.B.; IWAI, M.; FURTADO, V.V. \& CACCIARI, P.L., 1983. Parâmetros ambientais do Estreito de Bransfield. Inst. Oceanogr. Univ. São Paulo. 26 pp. (unpublished).

KELLER, R., 1983. Contribution to the early life history of Pleuragramma antarcticum Boul. 1902 (Pisces, Nototheniidae) in the Weddell Sea. Meeresforsch. 30: 10-24.

KELLERMANN, A. \& KOCK, K.H., 1984. Postlarval and juvenile notothenioids (Pisces - Perciformes) in the Southern Scotia Sea and Northern Weddell Sea during FIBEX 1981. Meeresforsch. 30: 82-93.

KELLERMANN, A. \& SLOSAFCZYK, W., 1984. Distribution of postlarval and juvenile Notothenioidei in the Atlantic Sector of the Southern Ocean during FIBEX 1981. BIOMASS Rep. Ser. (36): 1-27.

MUJICA, A. \& TORRES, A., 1982. Analisis cualitativo y cuantitativo del zooplancton Antarctico. INACH. Ser. Cient. (28): 181-191.

NORTH, A.W. \& WHITE, M.G., 1982. Key to fish postlarvae from the Scotia Sea, Antarctica. Cybium 6(1): 13-32. 
REGAN, C.T., 1916. Larval and postlarval fishes. Brit. Antarct. ("Terra Nova") Exped. Zool. 1(4): 125-156.

RASOANARIVO, R. \& ABOUSSOUAN, A., 1983. Larves de Electrona antarctica

(Günther, 1878) (Teleostei, Myctophidae) recoltees durant la campagne FIBEX-MD/25 dans le Sud-Ouest de L'Ocean Indien. Cybium, 7(2): 75-86. SINQUE, C.; KOBLITZ, S. \& COSTA, L.M.. 1986. Ichthyoplankton of Bransfield Strait - Antarctica. Nerítica 1 (3):

SLOSARCZYK, W. \& REMBISZEWSKI, J.M., 1982. The occurrence of juvenile Notothenioidei (Pisces) within krill concentrations in the region of the Bransfield Strait and the Southern Drake Passage. Pol. Polar Res. 3: 299312.

STEIN, M., 1979. Stratification and currents off Elephant Island in early February 1976. Meeresforsch. 27(1978/79): 75-87.

STEIN, M. \& SUSZCZEWSKI, S.R., 1983. Geostrophic currents in the South Shetland Islands area during FIBEX. Natn. Inst. of Polar Res., Tokyo (27): 23-34.

WÖRNER, F.G. \& JAMES, R., 1981. Early life history stages of the Antarctic fish Notothenia gibberifrons Lönnberg, 1905. Rapp. P.V. Réun. Cons. int. Explor. Mer, 178: 196.

YEFREMENKO, V.N., 1980. Description of the larvae of six species of the Family Chaenichthyidae from the Scotia Sea. J. Ichthyol. 19(3): 64-75. 


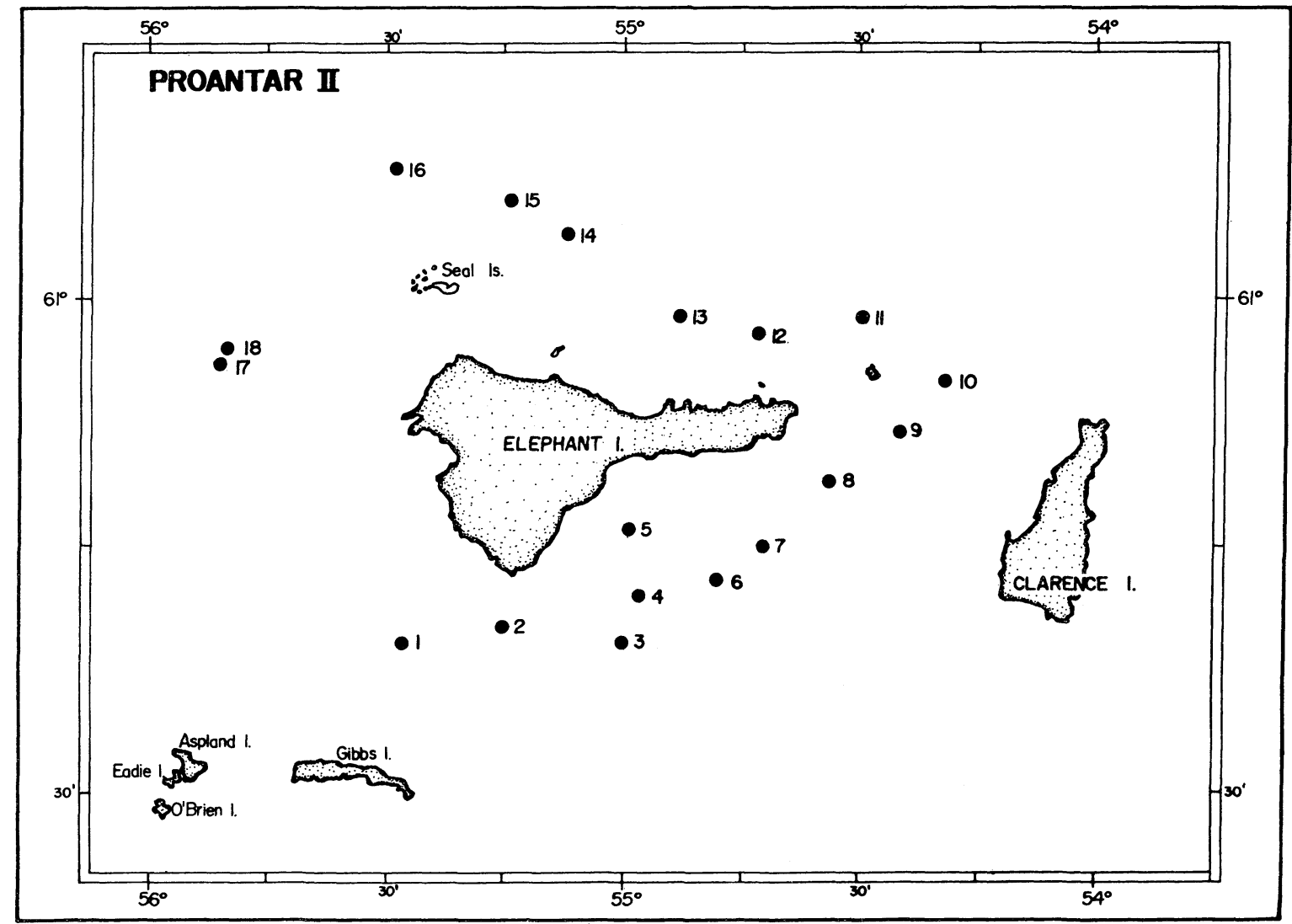

Fig. 1. Plankton sampling stations around the Elephant Island during the southern summer 1983/84. 


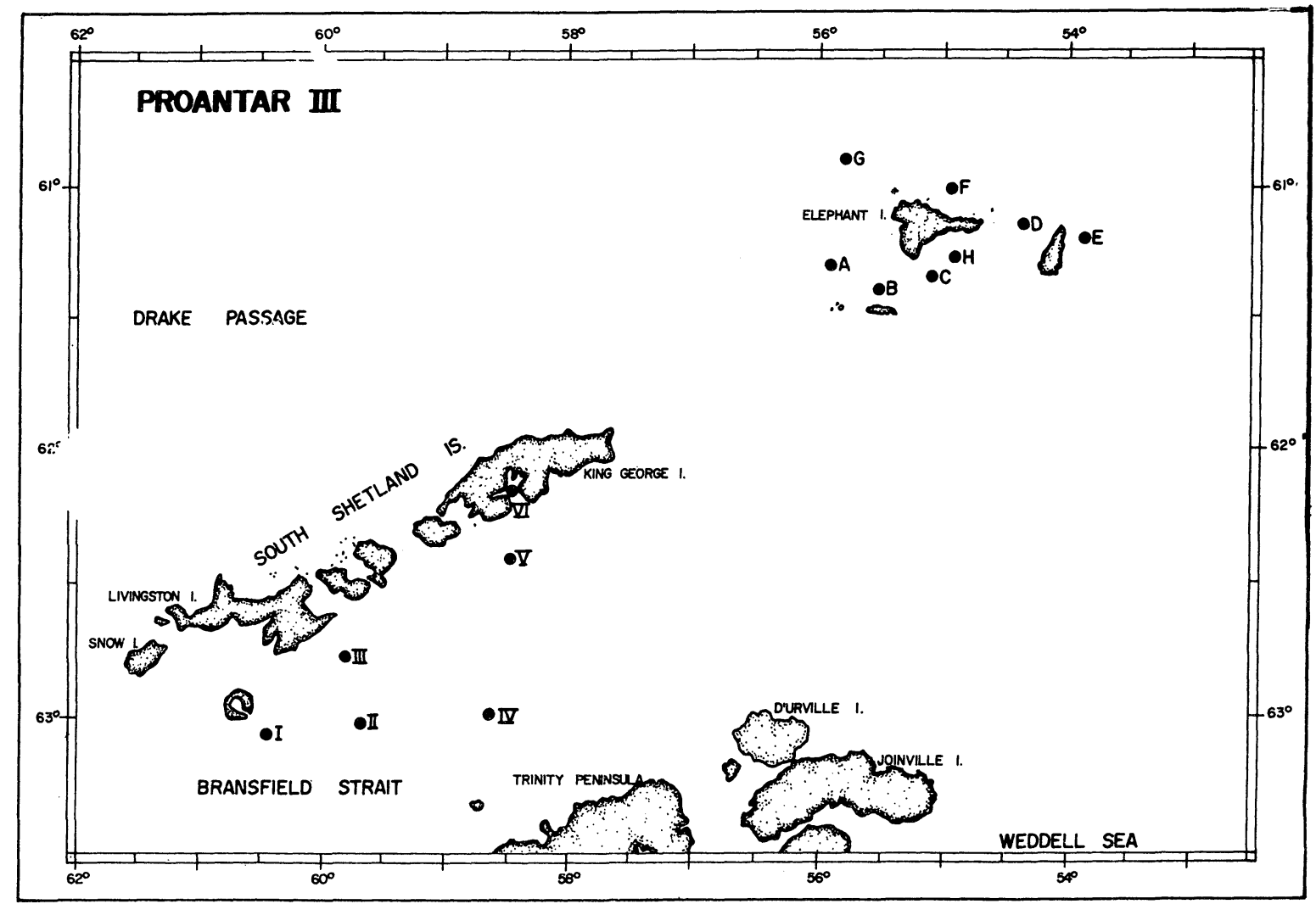

Fig. 2. Plankton sampling stations around the Elephant Island and Bransfield Strait during the southern summer 1984/85. 


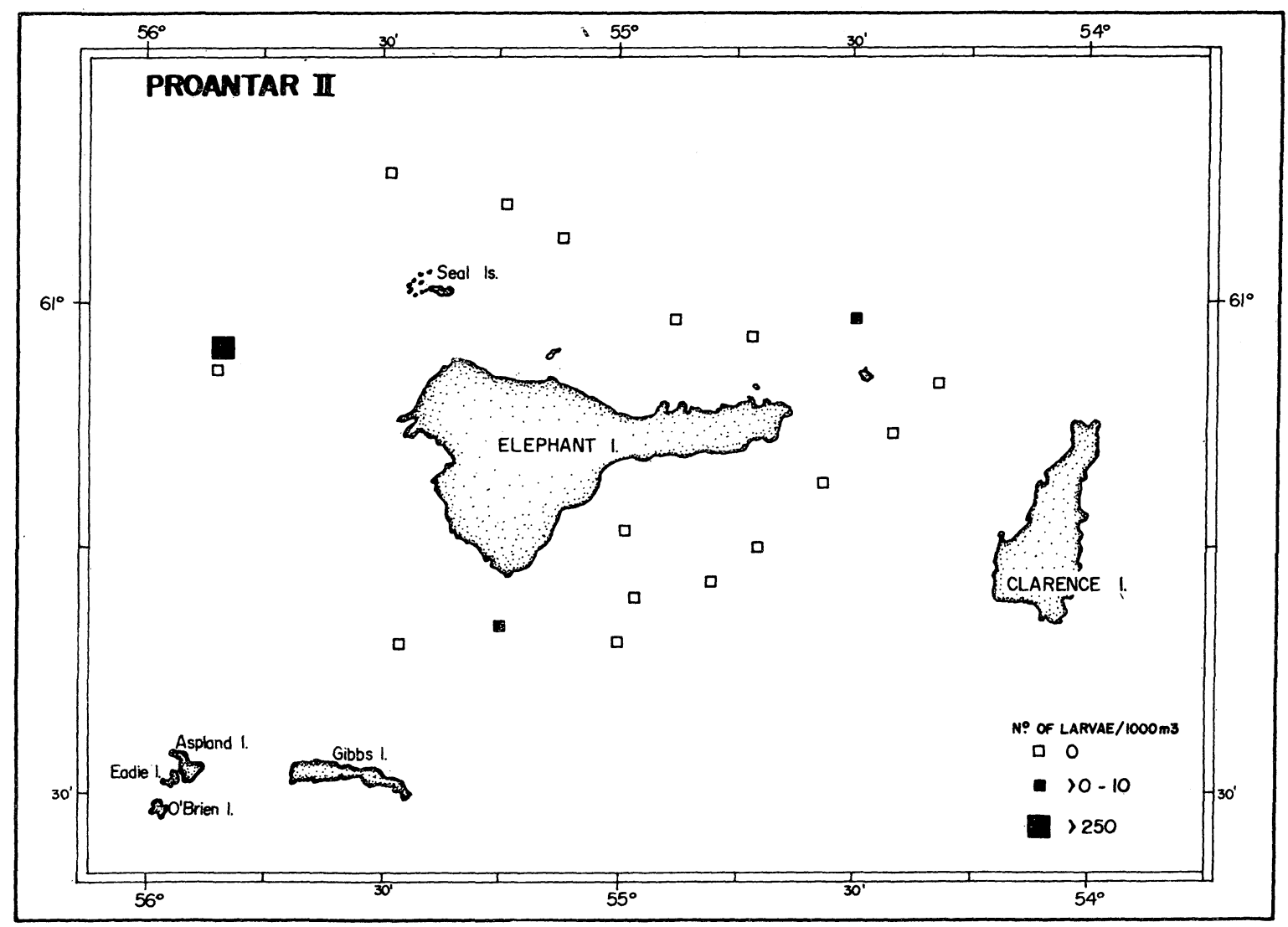

Fig. 3. Distribution, in density, of larvae and postlarvae Antarc tic fishes around the Elephant Island during the southern summer 1983/84. 


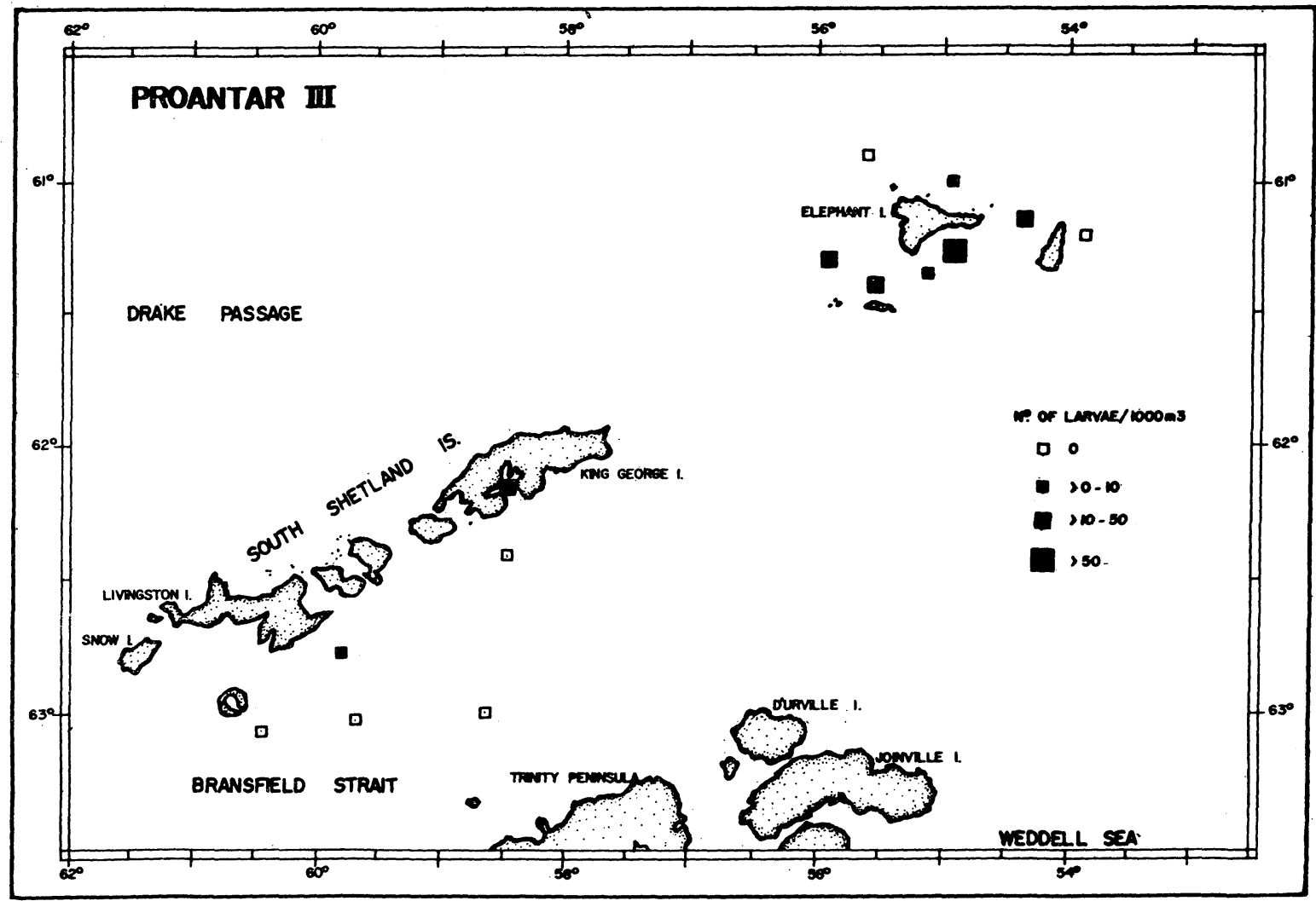

Fig. 4. Distribution, in density, of larvae and postlarvae Antarctic fishes around the Elephant Island and Bransfield Strait during the southern summer 1984/85. 

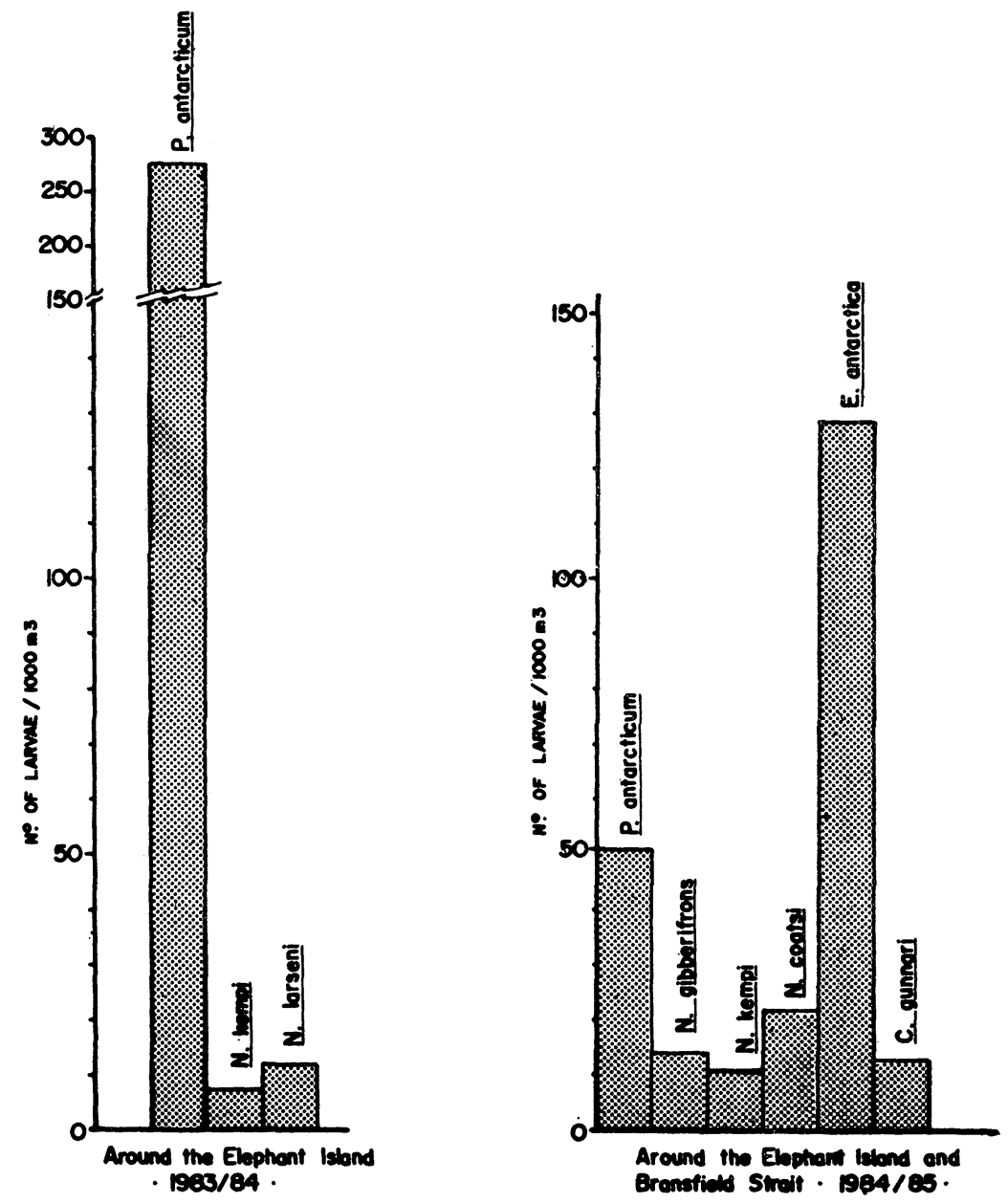

Fig. 5. Total abundance of larvae and postlarvae Antarctic fishes caught around the Elephant Island and Bransfield Strait during the southern summer $1983 / 84$ and $1984 / 85$. 


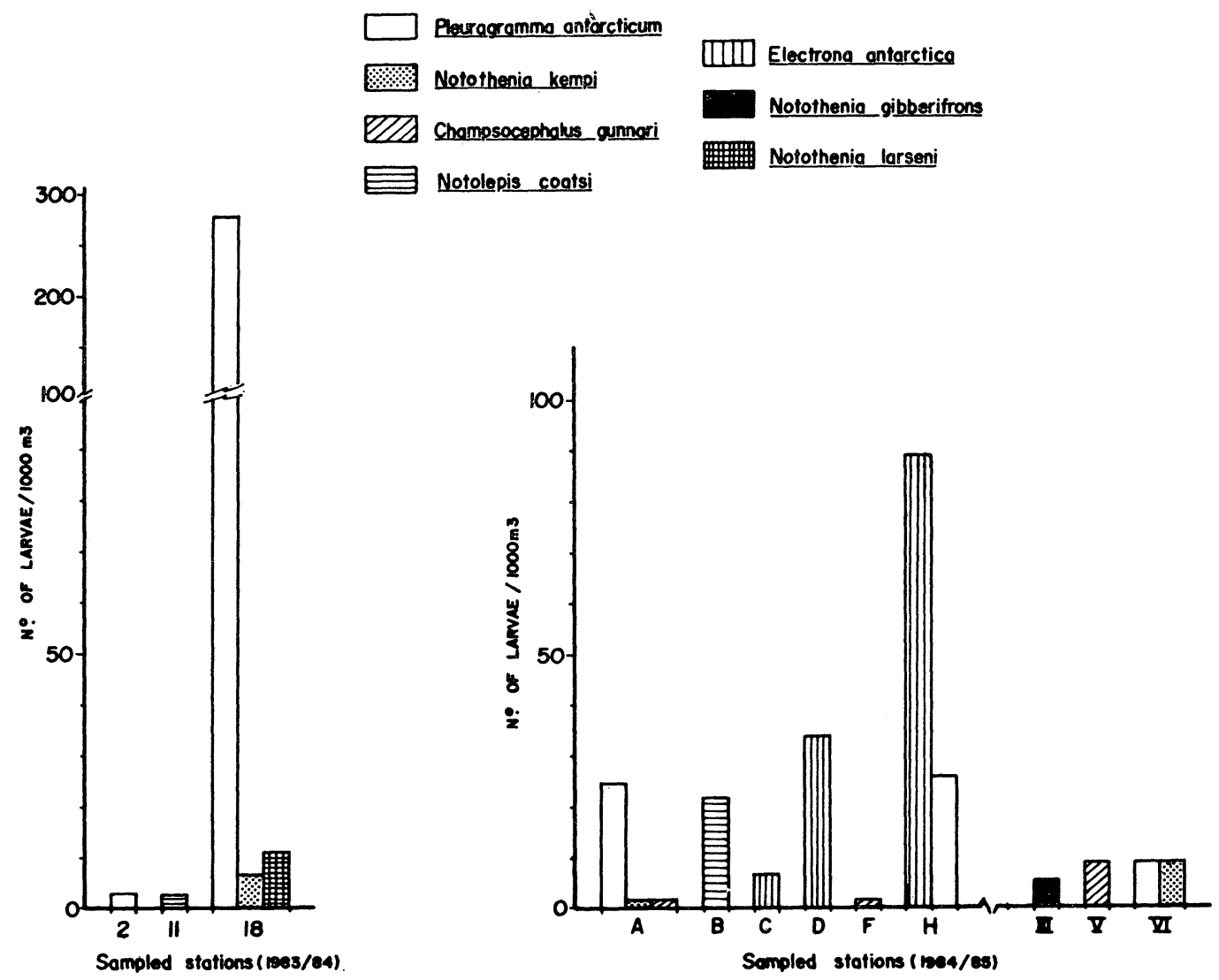

Fig. 6. Species density of larvae and postlarvae Antarctic fishes, at different sations during the southern summer 1983/84 and 1984/85. 

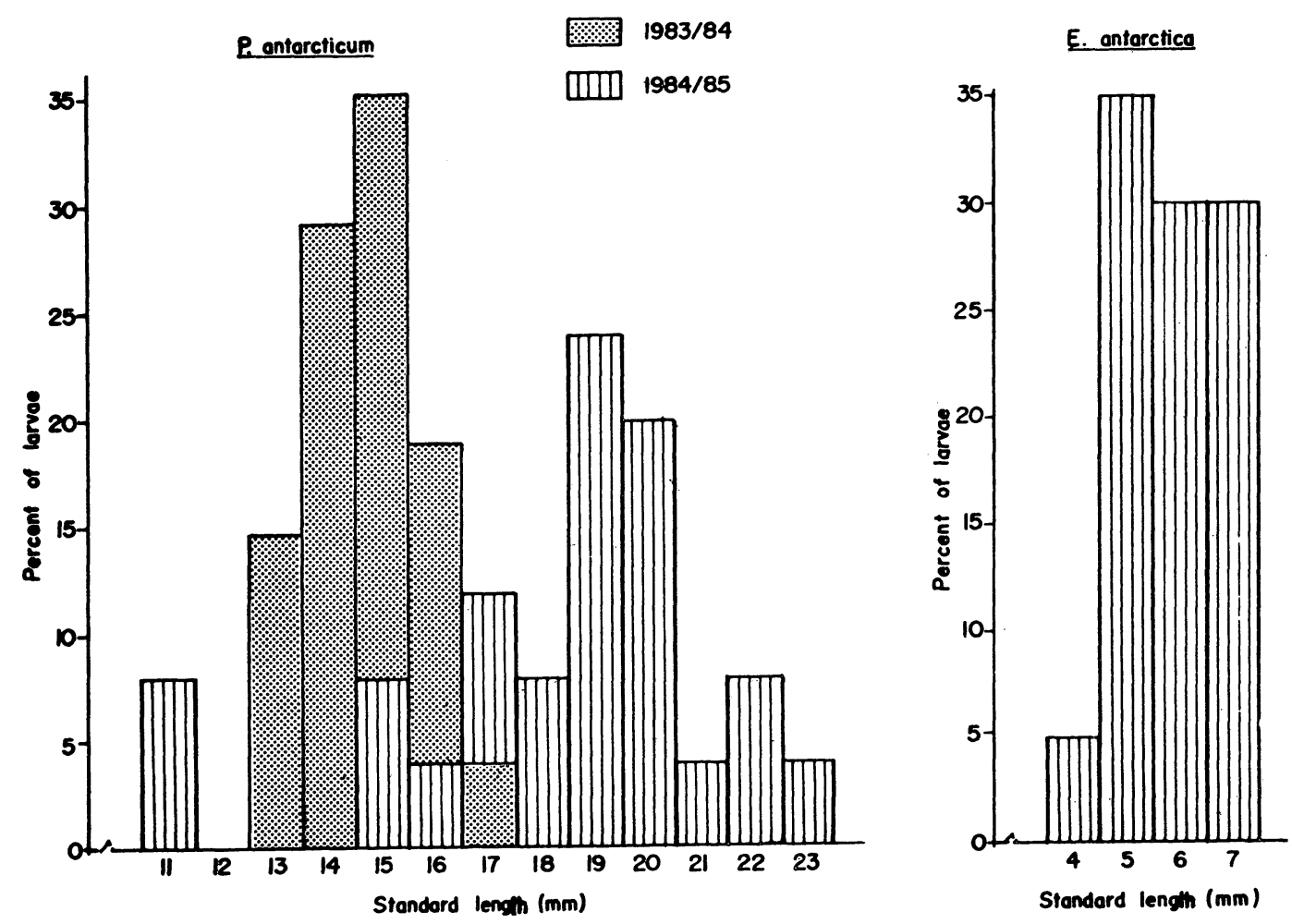

Fig. 7. Size frequency distribution of P. antarcticum and E. antarctica around the Elephant Island and Bransfield Strait during the southern summer 1983/84 and $1984 / 85$ 